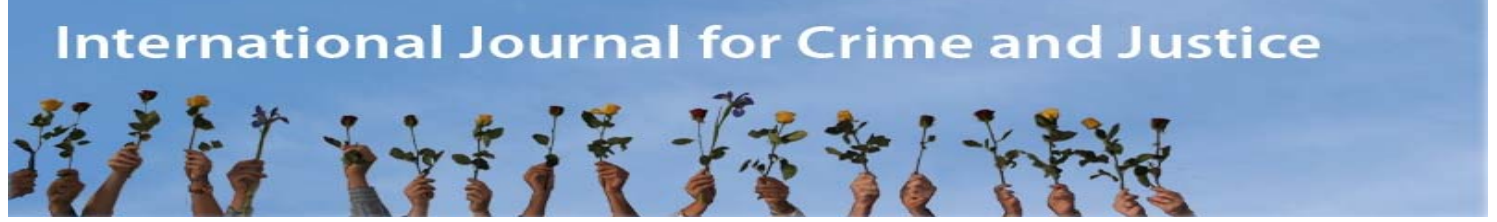

\title{
Populism, Law and Order and the Crimes of the 1\%
}

\section{Russell Hogg}

Queensland University of Technology

\begin{abstract}
The article examines the evidence of endemic financial crime in the global financial crisis (GFC), the legal impunity surrounding these crimes and the popular revolt against these abuses in the financial, political and legal systems. This is set against a consideration of the development since the 1970s of a conservative politics championing de-regulation, unfettered markets, welfare cuts and harsh law and order policies. On the one hand, this led to massively increased inequality and concentrations of wealth and political power in the hands of the super-rich, effectively placing them above the law, as the GFC revealed. On the other, a greatly enlarged, more punitive criminal justice system was directed at poor and minority communities. Explanations in terms of the rise of penal populism are helpful in explaining these developments, but it is argued they adopt a limited and reductionist view of populism, failing to see the prospects for a progressive populist politics to re-direct political attention to issues of inequality and corporate and white collar criminality.
\end{abstract}

\section{Key Words}

Corporate crime, global financial crisis, populism.

\section{Introduction}

The US and global financial meltdown (GFC) in 2008 was the most devastating economic crisis since the Great Depression of the 1930s. It inflicted trillions of dollars of damage on the world economy, bringing it to the brink of collapse. In the US and beyond, millions of people lost their jobs, their homes, their savings and their hopes for a better future. The repercussions continue to reverberate across the globe.

The scale and complexity of the economic and social disaster may seem to overwhelm attempts to arrive at understanding, let alone apportion any responsibility. One thing however is clear. Fraud and other individual and corporate abuses, practised on an industrial scale within the financial sector, played a major contributing role in the GFC. This was criminality borne of a culture of arrogance, greed and impunity. It was the product of a world in which financial innovation, calculation and manipulation were all but totally insulated from any guiding moral 
compass. This was due to a combination of factors: the social insularity of the finance sector, the role of technology and high level mathematical expertise, the unquestioning faith in free markets and the absence of any meaningful regulatory oversight, to name a few.

Sixties radicals have been excoriated by conservatives for decades now for mistaking freedom for licence but, if such a legacy of moral confusion exists, its leading practitioners are surely to be found not amongst the remnants of the counter-culture but in the ranks of a rapacious, amoral capitalism. Watching Charles Ferguson's award-winning documentary on the GFC, Inside $J o b$, the viewer is struck not simply by the evident greed, wrongdoing, and conflicts of interest but also by the uncomprehending banalities offered by some key players in response to any suggestion that corporate and personal conduct in the creation of the GFC raised questions of morality and ethics.

This article looks at the crimes of the GFC in the context of the politics of law and order over the last 40 years. The primary focus is the US but the global character of the GFC and political commonalities across the English-speaking world (in particular) hopefully make the analysis of broader relevance. With this wider canvas in mind, I begin with a recent case that captured national political and media attention in Australia in early 2013. When juxtaposed with official responses to crime and abuse in the GFC, it provides a remarkable case study in the social, moral, legal and political asymmetry that surrounds the crimes of business and the crimes of the rest. Edwin Sutherland's old question - 'is white collar crime, crime?' - continues to hang in the air like a dark cloud (Sutherland 1970, 1949).

Sutherland pioneered a criminology that was humanistic, political, egalitarian and populist. (More will be said about that last, much maligned, term later). He sought to address the mutually supportive biases in the criminological gaze and the administration of justice and their roots in inequalities of wealth and power. These concerns found a renewed political resonance with the appearance in 2011 of the Occupy movement - a mass popular protest at the economic and political abuses of the GFC. I briefly consider this development in the following section. The Occupy movement changed the 'political conversation' in America and beyond, giving rise to new possibilities, including in relation to how we think about the politics of crime and justice.

I then turn to a more detailed consideration of the crimes of the GFC. This is followed by an attempt to track some of their roots to the politics of de-regulation and unfettered markets, inaugurated in earnest by President Ronald Reagan in the US (and by Margaret Thatcher in Britain). The flip side of the 'Reagan revolution' was the growing hold exerted by a harsh populist stance on law and order. This produced another sort of revolution: the massive expansion of the US prison population. I try to summarise the political logic at work in rightwing populism which intensified the inequalities in both society and the administration of justice, and created some of the essential conditions for the crimes of the GFC and the broader political crisis it brought to a head.

It is usual (at least outside the US) for populism to be tacitly dismissed by academics and political commentators as an intrinsically reactionary and indeed pathological form of politics (Roberts et al. 2003; Freiberg and Gelb 2008; Bale et al. 2011; Hartcher 2011: ch 16). This has been the dominant underlying assumption in most accounts of penal populism that have explored the politics driving the widespread trends to penal excess in the US and elsewhere. I seek to challenge this view and to de-couple populism from its assumed natural allegiance to conservatism and punitive excess.

This is a necessary step in re-orienting progressive politics, including the politics of law and order, to confront questions of inequality in law and society and the destructive effects of concentrations of power. If this is to be achieved, it will likely involve not a banishing of populism but its recovery and reconfiguration for progressive ends. 


\section{Two laws: Crimes of, and crimes against, 'the market'}

When, in early 2013, a young Australian environmental activist, Jonathan Moylan, issued a hoax press release relating to a mining company's credit facility with a major bank, causing a temporary dive in the company share price, there was loud condemnation and insistent demands by business figures, politicians and the media for him to be criminally prosecuted and for changes to the law, if that was necessary, to punish such conduct (Hamilton 2013). The gravity of the conduct that momentarily misled the market and had the potential to foster market disorder had to be underscored by a robust statement of moral condemnation of the kind that only the criminal law could deliver. The demand by business, on this occasion, to use the criminal law to safeguard the integrity of markets makes for an interesting contrast with typical business attitudes to market regulation, let alone regulation involving use of criminal sanctions (Denniss 2013). Business regulators in Australia make sparing use of the criminal law. In the US it is a striking fact that no bank, nor any senior banker, has to date been criminally prosecuted as a result of the GFC. Instant pressure may be applied to prosecute an environmental activist for a minor stunt but failure to criminally prosecute people responsible for major financial crimes occasions barely a ripple of criticism in business, government and the media. As Madrick and Partnoy (2011) observed, 'The [US] federal government has been far more active in rescuing bankers than prosecuting them', with bail-out packages running into billions of dollars of American taxpayers' money. The bail-outs were seen (no doubt correctly) as essential to save the US and global financial systems, but they carried little in the way of conditions (for example, in relation to the restructuring of financial institutions or the paying of executives obscene bonuses) and there was no corresponding housing relief or other assistance for the victims of the crisis. For the culprits, business as usual was resumed, including powerful lobbying against financial reform.

There are times when a crime or crimes affords a popular lens through which to explore and depict the inner workings of a culture, whether it is the culture of an organisation, a government, a sector of society or perhaps a whole society. We are more familiar with the powerless - minorities, the poor, the 'underclass', youth subcultures - being viewed in this way, especially at moments of crisis. Criminology and sociology has produced an abundant literature on 'moral panic' to describe and account for such moments. Moral panic (like populism) is widely used as a pejorative. The terms are also rarely used in connection with outrage occasioned by the wrongs and harms of the powerful. Impunity for the crimes of the GFC arguably points to more than a profound, entrenched inequity in the legal system. It points to something rotten in the economic, political and moral fabric of a society. It was this something that sparked the Occupy movements in the US. But the manifestations of rottenness in corporate and political worlds are evident well beyond the shores of the US: to take just a few examples, in the media crimes of the Murdoch empire in Britain (as the Leveson Inquiry (2012) and analysis in Watson and Hickman (2012) show, more symptom of its corporate culture than any sort of aberration); the trail of death, destruction and corporate cynicism left by the 'killer company', James Hardie's asbestos industries in Australia and elsewhere (Peacock 2009); recurrent corruption scandals involving politicians and business in one society after another; and patterns of corporate exploitation of third world countries that produce catastrophe on a regular basis such as the collapse in April 2013 of a Bangladeshi garment factory known to be unsafe, resulting in the deaths of hundreds of workers (Anderson 2013). It is perhaps no surprise therefore that Occupy and similar movements are spreading around the world.

\section{Occupy, inequality and the $1 \%$}

The Occupy movement made its appearance on 17 September 2011 in New York with Occupy Wall Street and quickly spread around the country and across the world. It was part of a global trend which had recently seen massive popular protest movements spring up in the unlikeliest 
of places, like the Arab Spring mobilisations that despatched hitherto immoveable dictators in Tunisia and Egypt to the sudden shock of their western sponsors. Time magazine made 'The Protester' its Person of the Year for 2011 (Time 26/12/11). The Occupy revolt was triggered by the abuses of the financial sector that led to the GFC and more particularly by the political response to the financial abuses, which consisted of rewarding the abusers with multi-billion dollar bail-outs whilst preaching austerity to their victims. Read more deeply, it was a cry of protest against an economic and political system that manifestly had ceased to work for ordinary people and seemed mostly to serve only the interests of a rich and rapacious financial elite.

At about the same time, figures issued by the Congressional Budget Office showed that income inequality in the US had soared in the previous 30 years: the average income of the richest $1 \%$ had increased by $275 \%$ whilst that of the poorest fifth had risen by only $18 \%$. The share of national income of the top 1\% had more than doubled from $8 \%$ to $17 \%$ (and a disproportionate share of this went to a super-rich fraction of the 1\%) whilst that of the bottom $80 \%$ had fallen (Pear 2011). The 1\% captured the lion's share of income growth (roughly 60\%) over a 30 year period, with less than $9 \%$ going to the bottom $90 \%$, thus returning the country to something like the economic and social disparities of the 1920s (Mishel and Bivens 2011): 'In 2007, average annual incomes of the top one percent of households were 42 times greater than incomes of the bottom 90 percent (up from 14 times greater in 1979) and incomes of the top 0.1 percent were 220 times greater (up from 47 times greater in 1979).' (Mishel and Bivens 2011: 2). Endless rounds of tax cuts and deregulation (especially of the financial sector) had roughly doubled the latter's share of the national economy, enriched a few almost beyond belief and empowered them politically to a degree not seen since the early twentieth century.

The GFC - its antecedents, its impacts and its aftermath - showed what these numbers meant in human terms. The Occupy movement was instrumental in translating the manifold individual, local experiences of crisis into a collective understanding that captured popular attention, thrusting 'the inequalities of everyday life' into focus (Chomsky 2012: 9). The reductionism of the 99 to 1 was a compelling symbol that quickly entered the wider political, media and popular imagination. Whatever the direction that these movements may take in the future, it is now something of a cliché to say that they changed the 'political conversation'. Polls and other studies in the US quickly showed quite dramatic shifts in public perceptions of and attitudes to inequality, class conflict, the role of government and the performance of political institutions (Zeleny and Thee-Brenan 2011; Morin 2012). They also showed that the Occupy movement commanded sympathy amongst a large section of the population and across the political spectrum from self-described liberals, progressives and moderates (Dionne 2012: 46-47). It is surely also no coincidence that bastions of free market capitalist thought, like The Economist newspaper (2012) and the World Economic Forum, recently elevated growing inequality as one of the major challenges confronting contemporary governments.

The renewed emphasis on the politics of inequality is global in character, even if more muted in countries, like Australia, that staved off recession after the GFC and have not experienced anything like US inequality levels and trends. What all these countries, Australia no less than others, seem to share is a crisis of public confidence in their public institutions (government and politicians obviously but also the courts, law, the media, educational institutions and so on). A gulf between 'the people' and the political classes (broadly defined) has progressively widened over time (Nye et al. 1997; Burchell and Leigh 2002). The old institutions - political parties, trade unions, religious organisations - that mediated these relationships in the past, creating a degree of stable, mass social adhesion, have been in steady decline. In their place we find evidence of mass disaffection from the political system. The Occupy movement was not just a reaction to economic recession therefore but also to the 'recession of democracy' (Chomsky 2012: 12) with which it was seen to be intimately related: the widespread sense of disconnect 
between the lives, concerns and troubles of ordinary people and the priorities, elite circles and narrow managerial calculus of government.

These conditions tend to foster populist political movements of various kinds, whether from above and aimed at reconnecting electors to charismatic political leaders (like Margaret Thatcher's authoritarian populism (Hall 1980; 1983) and the 'Reagan revolution'), or from below that protest the failings of government and/or business elites (like the Tea Party and Occupy in their very different ways). I will say more about populism later, but one striking feature of populist politics in the English-speaking world over the last 30 or more years has been the prominent role accorded law and order. Rising crime rates and the supposed moral laxity of a legal system fallen under the influence of a new class of social scientific experts and rights advocates has been an essential ingredient in the culture wars waged by the new right against social democracy, the welfare state and the legacy of 60 s radicalism. The focus on crime, along with race, immigration, welfare, family values and moral permissiveness, artfully shifted the political landscape, tilting it rightward and away from issues like poverty, inequality and corporate power and influence. The politics of law and order played overwhelmingly in favour of those seeking to roll back government social provision and the regulation of corporate power whilst pursuing exemplary punitive measures against street crime and disorder, welfare cheats, non-white minorities, the urban poor and working class youth (Garland 2001; Alexander 2012; Lacey 2008; Stuntz 2011).

It is timely to ask whether the current moment might favour a different sort of law and order politics, one which ceases to be solely concerned with crime and disorder on the streets and begins to politically question the moral and legal laxity surrounding corporate crime and antisocial behaviour in the suites. If so, what role, if any, might populism play? Before considering these questions it is necessary to look more closely at the crimes of the GFC.

\section{The crimes of the GFC}

Notwithstanding the lack of prosecutions, we know quite a lot about the crimes at the heart of the GFC. Charles Ferguson, amongst others, has detailed at length the evidence of pervasive fraud and other crime within the US financial sector (Ferguson 2012; Geis 2011: ch 12; Koller 2012). Criminal activity was not confined to a few rogue operators but involved all the leading US investment banks, other financial institutions and many major foreign banks. Ferguson also traces the historical antecedents to this pattern of criminal conduct and shows how it was endemic to the workings of the financial sector. The crimes he details ranged through securities fraud, accounting fraud, bribery, perjury, and anti-trust violations, to name a few. Criminal dishonesty trailed off into other deceptive conduct like misleading investors, betting on the default of securities that firms had sold to their client-investors, and concealing evidence of loan defaults, practices which, if not criminal, were highly unethical. Many of the same banks were involved in other crimes including bid-rigging and collusion, tax evasion and money laundering (including for Latin American drug cartels: Taibbi 2013). There is also a substantial body of anecdotal evidence that personal crimes like drug taking, procuring prostitutes and credit card fraud were widespread amongst bankers (Ferguson 2012: 206-207). This is suggestive of a risktaking culture that traversed the public and private worlds of work and leisure, albeit the risks involved seemed never to include those of arrest and prosecution. Ferguson, with some justification, suggests that the financial sector had, by the time of the GFC, evolved into 'a semicriminal industry' (2012: 19).

The roots of the GFC are complex and more will be said about them below, but a crucial proximate factor was the growing use of a novel financial instrument known as credit derivatives and, in particular, their application to the home mortgage market after 2000 (see Tett 2009 for one of the best general accounts of the rise and spread of credit derivatives and 
their role in the GFC). Credit derivatives were widely, if erroneously, promoted as introducing increased efficiency and stability into financial markets because it was said they dispersed risk. More cautious voices warned that, rather than spreading risk, they likely masked and increased it. Although it grew massively from the 1980s on, with very little understanding except by insiders of what credit derivatives were and how they worked, the derivatives market escaped regulation. This was largely due to the free market ethos widely shared by the industry, the regulators (like the US Federal Reserve) and government, and the revolving doors that seemed so often to connect them. The spread of credit derivatives was also greatly facilitated by the progressive removal of traditional regulatory constraints on the financial sector that had safeguarded against reckless lending practices in the past.

The dangers increased with the expansion of the sub-prime housing mortgage market. Subprime mortgages involved loans to high risk borrowers (people with little or no capital and/or poor credit records). A new breed of unregulated mortgage lenders saw the opportunity of making a bonanza from these high risk/high profit loans. The interests of the investment banks dovetailed with those of the lenders, with whom they worked closely. The banks purchased and repackaged the loans into complex securities (known as collateralised debt obligations or CDOs) before selling them onto investors all over the world, often pension funds, municipal councils and so on. Both lenders and banks had an interest in dispensing with the credit standards traditionally observed in lending, because these loans delivered the highest returns whilst the risks of default were removed, or (more accurately) were commodified into a further source of profit by their securitisation in the form of CDOs. This turned incentives in relation to the creation and management of risk upside down, initiating a vicious spiral.

The frenzy of predatory lending entailed was, almost necessarily, supported by systematic fraudulent practices. These included fraudulently inflated valuations and the widespread forging of loan documents by lenders (all to the knowledge of the banks). Matt Taibbi cites a Credit Suisse report from 2006 indicating that almost half the sub-prime loans were fraudulent (2012a: 5). Banks discarded their own credit standards and internal processes and, in the relentless pursuit of funds to keep the frenzy going, sought to circumvent capital reserve requirements and other regulatory constraints, often by manipulating their own financial records to misrepresent their exposure to risk. Moving along the securitisation chain, investors were frequently deceived in relation to the nature of what the Australian Federal Court referred to as 'grotesquely complicated' financial products (Bathurst Regional Council v Local Government Financial Services Pty Ltd (No 5) [2012]). Information concerning actual risks and defaults was actively concealed and the banks even bet on the default of the very securities they were selling to their clients (Lewis 2011). Ratings agencies, chronically compromised by their own conflicts of interest with the investment banks that paid their fees, facilitated the whole process by granting AAA ratings to both the banks and their inscrutable financial innovations. There were many warnings as to the risks and problems, including FBI warnings in 2004 in relation to evidence of widespread fraud in the sub-prime mortgage industry (Ferguson 2012: 58-59), but nothing slowed the momentum as long as torrents of money were pouring in.

Although there have been no criminal prosecutions of major bankers or banks, civil legal action involving private parties and regulators (principally the Securities and Exchange Commission (SEC)) has been widespread. For instance, Goldman Sachs, Citibank, Merrill Lynch, JPMorgan Chase, Bank of America, Citigroup (that is to say, not marginal, rogue financial players but amongst the most powerful financial institutions in the world, and the list could be extended to include a host of large foreign banks as well) were all involved in major fraud and other financial malfeasance that has been uncovered in public inquiries, private civil actions and/or civil penalty cases brought by regulators, most of them resulting in multi-million (and sometimes billion) dollar settlements. 
One of the biggest SEC settlements was with Goldman Sachs for misleading investors in relation to complicated mortgage products. The bank paid over $\$ 550$ million, a vast sum until you discover that it earned nearly $\$ 8.5$ billion in 2010 (Madrick and Partnoy 2011). JPMorgan Chase settled a similar action for \$153.6 million (Wyatt 2011a; Madrick and Partnoy 2011). In 2011 the Bank of America paid $\$ 12.7$ billion to settle private claims brought against it by de-frauded customers. Bank of America also settled a 2010 case with the government for $\$ 137.7$ million involving allegations of bid rigging, collusion and fraud in relation to municipal bonds sales, resulting in massive financial losses to local government organisations, schools and hospitals (Washington Post 2010). Bank of America was one of the leading beneficiaries of government bail-outs, having $\$ 45$ billion of taxpayer funds dumped into its coffers (on Bank of America generally, see Taibbi 2012a). Tens of other banks were involved in similar scams (Taibbi 2012b).

The fraud and malfeasance did not cease with the financial collapse. Rather, the frenzy of predatory lending gave way to a frenzy of predatory home foreclosures, roughly four million between 2007 and early 2012. This too involved recourse to widespread fraud, perjury and other abuse (what came to be known as 'robo-signing') as lenders fabricated foreclosure documents in a rush to process them, on occasions resulting in non-defaulting home owners losing their properties. In early 2012, five of the biggest banks, including Bank of America and JPMorgan Chase, agreed with government regulators to a $\$ 26$ billion settlement over foreclosure abuses. This was followed by another $\$ 8.5$ billion settlement in early 2013 with these same and some other banks (New York Times 2013).

In 2012 the Australian Federal Court found that more than a dozen Australian councils had been deceived into buying toxic financial products rated AAA by Standard and Poor's (S\&P). The Court ordered the ratings agency to pay almost $\$ 20$ million in damages (Bathurst Regional Council v Local Government Financial Services Pty Ltd (No 5). Based on the findings of the 2010 US Financial Crisis Inquiry Commission, the US Justice Department has also initiated a civil action against S\&P, alleging double-dealing, fraud and conflicts of interest arising from dozens of S\&P ratings on mortgage-based securities issued between 2004 and 2007. Ratings agencies like S\&P have been aptly described as accessories before the fact to bank malfeasance in the GFC. Far from ratings being based on sound modelling, they were driven by financial self-interest. The banks were their paymasters (Potter 2013).

The housing boom in the early 2000s did not inaugurate large-scale financial wrongdoing, there being a long history of fraud and other swindles associated with financial crises (Kindleberger 1996: 66-82). But the boom turbo-charged practices that had, over the previous 20 years, settled into a pattern described by Ferguson:

... since deregulation, no other major industry has broken the law so often and so seriously - behaviour, moreover, that is now rarely punished. For the last quarter of a century even highly criminal behaviour has typically resulted at most in civil settlements in which the institution admits nothing, promises not to do it again, pays a fine - and then promptly does it again. Rarely are individual executives even sued, or fined, much less criminally prosecuted. The fines are generally trivial, a minor cost of doing business, paid by the institution, or frequently, by insurance. Thus, while the housing bubble and financial crisis contain the largest and most recent episodes of financial sector misbehaviour, they are far from isolated. (2012: 159)

The GFC did nothing to bring about an immediate significant change in this pattern. A $2011 \mathrm{New}$ York Times analysis of SEC civil penalty enforcement actions over the previous 15 years found 51 cases in which a 'who's who' of Wall Street firms (19 in all) had broken antifraud laws they 
had previously pledged in settlements not to breach. In each subsequent case, the firm made a further promise not to breach the law, after breaking the earlier promises not to do so (Wyatt 2011b). JPMorgan Chase settled six fraud cases in the previous 13 years; Bank of America and Merrill Lynch (which had merged in 2009) settled 15 fraud cases between them; Citigroup settled six fraud cases over an 11 year period. Other recidivists included Goldman Sachs, Morgan Stanley and American International Group.

The wholesale abnegation of criminal sanctions in the face of repeated wrongdoing sends a powerful symbolic message concerning the entrenched inequalities of the economic, social and political system and the way in which some - the rich and powerful - are above the law. The announced need for flexibility, understanding, negotiation and compromise where white collar and corporate crime is concerned is a form of moral camouflage, implying (against all the evidence) that there is no culpability (or perhaps even agency) involved, that these are not deliberate wrongs but unknowing, unfortunate errors of judgment or mere technical breaches.

Ironically, the evacuation of morality - by making excuses and refusing to name wrongdoing and hold offenders responsible - is precisely the charge that neo-conservatives and free market advocates had been levelling at liberals, social democrats and radicals since the 1960s. They made a crusade of restoring punishment, deterrence and moral turpitude to a central role in law enforcement. Bright moral lines had to be drawn. They became manifest in the popular currency of notions like 'zero tolerance', ' 3 strikes and you're out' and 'just say No!' (to cite Nancy Reagan's popular exhortation to abstinence in respect of illicit drugs (Bertram et al. 1996: 111)) in the prevailing penal zeitgeist. How was this seemingly contradictory posture made possible?

\section{The 'Reagan revolution' and the roots of the GFC}

We now have many valuable accounts of what happened in the GFC and how it happened (Tett 2009; Sachs 2012; Stiglitz 2010, 2012; Ferguson 2012). The GFC was no accident but rather the consequence, in large part, of the concerted de-regulation of the US financial sector over a 25 year period and the expanding role and influence of that sector in the US and global economy. It began with the presidency of Ronald Reagan (1980-1988). On the other side of the Atlantic, Margaret Thatcher (British prime minister from 1979-1990) played an equally decisive political and ideological role.

In Reagan's case, his political rise was itself a culmination of sorts of the growing hegemony within the Republican Party of a southern and south western-based right-wing populism with a creed which centred on market freedom, small government, low taxes, welfare cuts and tough crime policies (Lind 1997). Critical accounts of the rise of right-wing populist politics in the US point out that the key to success depended on being able to constantly 'change the subject' (Lind 1997: 137; Berman 1994) from economic discontents and concerns to cultural resentments over race, immigration, family values, abortion, gay marriage, public education, the role of the courts and, of course, crime. The culture war strategy was one that was consciously proposed by Reagan strategists (like Lee Atwater) and adopted in Republican political campaigns. Conservatives argued that core American values of individualism, free enterprise and selfreliance were being destroyed by socialists, radicals and liberals. Although the political and cultural backlash was sparked by 60s radicalism, the roots of the disease were said to lie in the New Deal order and social democracy, with their stress on government regulation of markets and the expansion of welfare state provision. Avid readers of Friedrich Hayek's neo-liberal tract, The Road to Serfdom (1944 (1976)), sought nothing less than the evisceration of postDepression political, economic and social orthodoxy. The mixed economy, Keynesian management techniques and the welfare state had to go because they put societies on the slippery slope to socialism and communism. In seeking to extend the New Deal order to include Blacks, other minorities and the urban poor, Lyndon Johnson's 'Great Society' social programs 
and the 60 s 'rights revolution' represented no more than a further radical slide towards socialist tyranny.

The events of the 60s provided an important wedge for the new right. White working class voters who later became 'Reagan Democrats' (or working class Tories in Britain or 'Howard's battlers' in Australia) mostly remained committed to major components of the social democratic state, as evidenced by the fact that even ideological leaders like Thatcher and Reagan drew a pragmatic line at destroying many of them (the National Health Service in Britain, social security and even key Johnson initiatives like Medicare in the US). However, when persuaded that their hard-earned taxes were being wasted by government on failed special programs for undeserving minorities, 'welfare mothers' and criminals whilst the interests and values of the solid, thrifty, law-abiding mainstream were being overlooked, the possibility for fundamental political realignments did arise. So, it was argued, ordinary, hard-working people were not only victims of rising rates of street crime but also of government neglect, insensitivity and arrogance, a moral trashing of their values and a misuse of their taxes to subsidise the lifestyles of the unfit and undeserving. Representing government programs for minorities, the urban poor and other socially excluded groups through the prism of crime and welfare thus allowed for a much broader based assault on 'big government' and its 'tax and spend' policies.

Crime became a pivotal issue for right-wing populist politics because it could knit together a variety of social and cultural grievances and anxieties, beyond any concern about crime. The problem was not just rising crime rates but also that governments and a new class of liberal experts appeared to be more on the side of the criminal than the victims. Their value-free structural and social explanations provided excuses for wrongdoing and dispensed with morality and personal responsibility. They encouraged instead a sense of entitlement and fostered a culture of dependency. The problem was not economic and social exclusion but the repudiation of moral responsibility, self-reliance and the work ethic (see Katz 1989 for an account of this turn in political and public policy discourse).

For the conservative right, the solution lay in restoring the discipline of the market. Individuals would be taught that material reward and self-improvement came only with effort, hard work and thrift and that there was no place for sponging off the state or one's fellow citizens. But the moral foundations of society having been weakened under the influence of misguided liberal policies and attitudes, it was also necessary to fortify the state in its traditional role of guardian of law and order and national security by strengthening its policing and penal arms.

When the cultural discontents of the 60 s and 70s converged with the tax revolt at the end of the $70 \mathrm{~s}$, the scene was set for the Reagan and Thatcher revolutions. The governing philosophy guiding these revolutions was summed up in Ronald Reagan's Inaugural Address as President in January 1981:

In the present crisis, government is not the solution to our problem; government is the problem.

The crisis was also economic. If deficits and inflation could be blamed on big-spending government that threw the hard-earned money of tax payers at undeserving and ungrateful minorities, and then only to worsen rather than remedy problems like crime and poverty, this opened the way to a virtuous roll-back of the state in favour of unfettered market forces.

In the event, Reagan rolled back the state in many areas although he also contributed to future deficits through massive increases in military spending. And notwithstanding his populist rhetoric, Reagan's policies overwhelmingly favoured business and the wealthy. Most of the tax cuts went to the rich. Together with de-regulatory policies, this contributed to the everwidening gap between rich and poor in the following three decades (Berman 1994: 92). The de- 
regulation of the financial sector initiated by Reagan and continued with gusto by his successors, including Bill Clinton, had far-reaching consequences (Ferguson 2012: ch 2; Sachs 2012: ch 4, esp 61-62).

Traditional controls on banking, like the New Deal-era Glass-Steagall Act, 1933 (which was weakened by Reagan and ultimately repealed by Clinton), were designed to ensure prudent lending practices by restricting the size of banks, by erecting walls within the financial sector (between commercial banking, investment banking, home lending and insurance), and by limiting the capacity of banks to engage in speculative investments with others people's money. The sector was tightly regulated. To be sure, de-regulation was not the only force at work in the progressive financialisation of the US (and global) economies. There were also the accumulating economic pressures from the appearance of 'stagflation' and the oil shocks in the 1970s and the far-reaching impact of new technologies. But, as Ferguson put it, de-regulation had the effect of 'putting the inmates in charge of the asylum' (2012: 30). Relaxation of controls saw bank mergers, the rise of vastly bigger, more aggressive banks and a much enlarged financial sector with enormous economic power. This in turn translated into overweening political influence exerted through industry lobbying capacity (three lobbyists for every elected US representative, according to some accounts), through campaign financing, and through the constant exchange of personnel as between the senior ranks of Wall Street, government and the regulatory agencies. It meant that, in the teeth of rapid growth and change involving the advent of complex, risky financial innovations like for example derivatives (described by Warren Buffet as 'financial weapons of mass destruction'), doctrinaire adherence to free market abstractions peremptorily ruled out any consideration of regulation.

This was a case of money taking over politics or, in a word, plutocracy. Such a level of capture meant that industries effectively wrote their own laws and rules. As Stiglitz (2012) and others show, the relentless push for yet further de-regulation frequently had little to do with drives for efficiency and productivity, and everything to do with the abuse of monopoly economic power in the service of rent-seeking and the creation of a weak framework of laws. When governments offer resistance, they are loudly accused of being 'anti-business', of engaging in 'class war' or undermining 'market confidence'.

Reagan succeeded in executing the 'culture war' strategy of 'changing the subject', of 'redirecting populist resentment of the rich toward a governmental establishment that supported a liberal social and cultural agenda' (Berman 1994: 3). Under cover of returning power from government to the people, Reagan actually handed power and wealth on a massive scale to business and the rich. Margaret Thatcher prosecuted a similar strategy in Britain. Centre-left politicians in the US and elsewhere (Tony Blair in Britain and, sometimes with less enthusiasm and more balance, state and federal Labor leaders in Australia) adjusted to the new free market dispensation and political outlook: light touch regulation of the economy coupled with a much tougher, more punitive attitude to welfare and crime.

The record of the US on crime and punishment speaks for itself: the reflex political commitment to harsh rhetoric and harsh policies led to a five-fold increase in the national imprisonment rate in the 30 years after the mid-70s, giving the US the dubious honour of having more of its citizens in prison per capita than any other nation in the world. Other countries, particularly in the Anglo world, followed suit, greatly expanding their penal systems (if nowhere to the same degree as the US) and elevating penal severity as a core litmus test of political resolution and legitimacy. 


\section{Crime and populist politics}

The concept of penal populism has assumed an important role in explanations of penal excess and the growing criminalisation of the poor and minorities (Bottoms 1995; Garland 2001: 13; Roberts et al. 2003; Pratt 2006; Freiberg and Gelb 2008). In most accounts, populism is seen as intrinsically punitive in nature. It serves the interests of political leaders to channel the discontents of ordinary people into demands for tougher measures against symbolic 'folk devils', like black street offenders, welfare cheats and illegal immigrants, and away from their real and complex causes in declining economic security and rising inequality. It also provides an explanation for how, ideologically and politically, the fundamental inequities of the legal system are legitimated as the public gaze is diverted from the pervasive, calculated and harmful crimes of business and corporations. The populist politics of the American right since the 1960s adopted this as a conscious political strategy, one that successfully shifted public debate rightward and thus ensnared the centre left.

There is a problem, however, in treating the connection between populism on the one hand, and conservatism and punitiveness on the other, as essential rather than contingent. Elsewhere I have relied on the theoretical analysis of Ernesto Laclau (2007) to develop the argument that populism needs to be de-coupled from punitiveness and, indeed, from any necessary social or ideological belonging or content, and taken seriously as a political rationality in its own right (Hogg 2013). Instead of being seen as a perversion of democracy, it should be regarded as a regular, meaningful, 'normal' dimension of political practice. To assume the Olympian attitude, so prevalent in casual academic and political critique, that populism only has to be named to be exposed as a dangerous political aberration and sham, is to reproduce the very political habits and prejudices (elitism, rationalism, intellectualism) that populism so successfully attacks.

Populists (self-described or otherwise) typically call for power to be returned to 'the people'. This of course begs obvious questions. More accurately, what populist movements and interventions are engaged in when they make such appeals is a process of constituting the people' as a political identity and active political force. It almost goes with saying that 'the people' in question are not the people as a whole or even necessarily a majority or plurality. Populism operates in the space that invariably exists between the (heterogeneous, fragmented, inarticulate) claims and desires of people within a political formation and that formation's power structures, working to convert disparate disaffection into an organised political movement. The people in question tend to be those who are, or see themselves, as normally outside politics, as without a voice in the halls of power and in organised interests and lobbies. More than this, populist interventions represent 'the people' as victims of a system of power, which is either corrupt or indifferent to their needs and values. Populist mobilisations therefore tend to be organised around a sharply drawn principle of social antagonism. It is important to recognise also that the psycho-social processes involved are not necessarily logical in nature or simply interest- or ideas-based, but commonly depend on non-rational, affective, political identifications with a movement, leaders, symbols and ideas. Those who see this as dangerous are doubtless correct but they overlook the fact that it is a danger inherent in all politics because affective appeal is integral to politics.

Truncated as this summary of more complex arguments is, I hope it suffices to rescue populism from its fate as political aberration. Taking the populism in penal populism seriously requires thought to be given to what a progressive populism around law and order might look like. Ideas around restorative justice and justice reinvestment, for example (Brown 2013; Hogg 2013), provide promising avenues for progressives to popularly contest punitive agendas. I want also to suggest that a progressive populism might direct far greater attention to corporate and white collar crime, revisiting and developing the legacy of Edwin Sutherland's criminology. This would 
complement the broader political goal of confronting inequality and plutocracy that movements like Occupy have firmly placed back on the public agenda.

\section{Populism and corporate and white collar crime}

Edwin Sutherland was not the first thinker to highlight the phenomenon of business crimes amongst the well-do-to and outwardly respectable classes. In his pioneering sociological study, The Philadelphia Negro (1899), published many decades before Sutherland's time, the AfroAmerican sociologist and activist WEB Du Bois explained that the over-representation of Black Americans in prisons was due in part to the legal impunity enjoyed by the crimes of the white business class. Other scholar-activists and writers in the early 'muck-raking' tradition, figures like EA Ross and Upton Sinclair (1906), also drew public attention to the crimes and harms perpetrated by business, as did early populist political movements in the US and Australia (Love 1984). But it was Sutherland who successfully popularised the term 'white collar crime' in and after his 1939 presidential address to a joint meeting of the American Sociological Association and the American Economic Association. And before and since, evidence of harms perpetrated by corporations and wealthy and powerful business people has not been lacking (Geis 2011). Sutherland, and many of the criminologists who followed his lead in researching and theorising around crimes of the powerful, conceived the project in broadly political, as well as intellectual, terms. They aimed to expose the highly selective (and thus ultimately political) nature of the criminal process, to redress manifest biases by drawing attention to the scale and impact of corporate and white collar crimes and harms, and (and most ambitiously) to tackle the inequalities in wealth and power that underpinned a system in which harm was perpetrated on a large scale but responsibility for it effectively denied or deflected. This tradition has produced an impressive body of research and theory, and notched up significant policy achievements. Many of these achievements lie in the field of improved regulation of corporate and business activity. This is not to be dismissed, but it does tend to underline that there has been far less success on the larger political, social and moral questions posed by the selective criminalisation of working class crime and the pervasive legal and moral ambiguity (and often straightforward impunity) surrounding business malfeasance; and illustrate how these relate to systemic economic, social and political inequalities.

America is perhaps the one country in which the term populism is openly embraced and in which it carries positive overtones, especially on the left or progressive side of politics. This stretches back to the emergence of the self-described populist movement in the late nineteenth century. It began with the agrarian revolt and saw the establishment of the People's Party as a formidable third party force in the 1880s and 90s which won state and local political office in many parts of the south and west and secured over a million votes in the 1892 presidential election before supporting Democrat William Jennings Bryan in the 1896 presidential race (Goodwyn 1976; Kazin 1998). The agrarian revolt saw farmers join forces with workers and radical intellectuals to defend the interests of the common people against the big financial, rail and other corporations whose rapidly growing wealth and influence in the 'gilded age' of unregulated US capitalism was used to mercilessly exploit and oppress small producers and workers and to dominate and corrupt the political process. The vision, goals and methods of the populists have exerted a continuing influence on American left and progressive politics (Kazin 1998; Dionne 2012; Boyte and Riesssman 1986). But, as Kazin shows, in confirmation that populist politics have no essential ideological or social underpinnings or content, populism was for much of the twentieth century a feature of right wing movements in the US, including McCarthyism, the Goldwater insurgency in the Republican Party in the 1960s, the George Wallace-led backlash against civil rights and desegregation, the Reagan ascendancy and, most recently, the Tea Party. 
Interestingly, Gil Geis (2011: 5-6; also see Shover and Cullen 2008) has recently suggested that Edwin Sutherland's political education and his interest in white collar crime were shaped by the populist milieu of Nebraska in the late nineteenth and early twentieth centuries in which Sutherland grew up, Nebraska being one of the populist strongholds at the time and the home state of William Jennings Bryan. Whatever the direct influence of populism on Sutherland, his approach to white collar crime resonates powerfully with the concerns of the populists in its rejection of received legal categories of crime, its explicit concern with the political character of crime definitions, and its central preoccupation with the corporate setting and respectable upper class status of white collar offenders (and thus with questions of power and economic inequality). This led Shover and Cullen (2008) to label as 'populist' the more politicised and reform-oriented tradition of research and theorising around white collar crime initiated by Sutherland. For once the intent behind the label was not pejorative. They contrast this with what they call the 'patrician' perspective, a more conservative, narrower, legalistic approach favoured by a later generation of criminologists, whose ranks and influence were (unsurprisingly) enhanced by more generous funding pipelines.

The answer given by the 'patricians' to Sutherland's question - is white collar crime, crime? - is 'no, not unless it is prosecuted as such'. This begs the question of why it is typically only smalltime transgressors who are prosecuted for economic crimes and thus become the exclusive subjects of research in the 'patrician' tradition. This approach reflects, as it reproduces, the 'ambiguity' surrounding white collar and corporate crimes. But ambiguity is not an inherent quality of conduct: it is an effect of how conduct is legally defined and processed, how it is constructed in media and political discourse, and so on. Punitive criminal law seeks to speak to us all, as members of a civic community who carry certain general moral obligations to our fellow citizens (Duff 2012). It condemns and punishes conduct on behalf of the community as a whole because the conduct is regarded as violating fundamental moral norms upon which civic life is held to depend. Punitive law has an overwhelmingly normative and moral character and purpose. Such legal rituals (which are crucially moral and political also) are only exceptionally enacted against white collar and corporate offending, as the GFC amply demonstrates.

More typical are civil and regulatory sanctions (although sparing use is often made even of these laws). They tend to be morally neutral: less concerned with the individual violation and the moral status of its perpetrator than with modulating the overall level of the activity in question or compensating for harm. Cases are often settled or disposed of administratively or in low-key legal proceedings and usually away from the glare of publicity. Strict liability is common, although the effect of this is often to obscure the actual presence of moral culpability rather than simply weaken legal requirements to prove guilt. The predominance of monetised justice - fines, civil damages, civil penalties - serves also to blur the line between civil and criminal (O'Malley 2009). Imposing a price on wrongdoing assimilates sanctions to the generalised monetary circuits of capitalist society, making it just another cost of doing business and diluting, if not effacing, its moral status.

Kit Carson's path-breaking historical and empirical research on factory crimes and their enforcement showed how in Britain these crimes became 'conventionalized'; that is to say, how certain legal wrongs involving the manufacturing class came to enjoy substantial immunity from the criminal law, how their status was transformed into not being 'real crimes' at all (Carson 1979; 1971). He refers to Foucault's analysis of the way in which the advent of industrial capitalism led to a 'restructuring of the economy of illegalities' (1977). A more extensive and strictly enforced regime of criminal laws and disciplinary punishments (with the penitentiary at its centre) was directed at working class crimes, many of which had in the past not been crimes at all or, if illegal, enjoyed a broad immunity based on popularly entrenched notions of customary right (for example, in relation to hunting and fishing on common lands). New categories of theft, draconian punishments and eventually new models of policing were enlisted 
in campaigns to repress the old customary rights. The new crimes enacted under factory laws, however, rather quickly had their criminal status diluted, were exempted from punitive law and made subject to a very different regime of, at best, light-touch controls. Rather than reflecting some natural order of things, the 'institutionalisation of ambiguity' was the historically contingent outcome of legal and political struggles, campaigns and conflict.

Sutherland was certainly alert to the manner in which the response to white collar and corporate crime (of the law, government, news media) shaped public moral sentiments rather than merely reflecting them. In the 'patrician' perspective, the wrongdoing of corporations and wealthy businesspeople is safely sealed off from the sort of emotional fervour and overt moralising stirred by penal populism in respect of other crimes. It is firmly contained within a sanitised administrative logic devoid of moral and political content. The taken-for-granted basis for this is that corporate and white collar harms are embedded in legitimate market practices and processes which provide the essential foundations of economic life. Regulation should not interfere with the efficient allocation of resources in a market economy. That market mechanisms tend towards a self-sustaining equilibrium provides a convenient frame through which to explain (away) facts like the substantial screening out of so much of this crime from the criminal justice system, the failure of government bureaux to collect and publicise data on these criminal activities, and so on. Those who question legal definitions and the selective role of the criminal justice system with respect to economic crimes are frequently accused of being unscientific and politically motivated, an apologia that goes back to Paul Tappan's response to Sutherland (Tappan 1970). It is also held to be imperative that the 'spill-over' effects and externalities of corporate punishment (collateral costs borne by innocent shareholders, employees and consumers) be avoided (see, for example, Coffee 1981), a calculus that has never enjoyed much currency where the punishment of lower-class crime was concerned. There is a 'spill-over' effect but it works in the opposite direction to the one Coffee referred to: the supposed legitimacy and productive character of business activity routinely shields business wrongdoing from scrutiny and censure. There is a particular irony when it comes to the financial sector as so much of its activity, in areas like derivatives for example, is of doubtful productive value to the real economy, whether or not it is conducted in a wholly legal manner.

In characteristic populist fashion, the Occupy movement has sought to turn this on its head: outrage at unpunished financial abuses has focussed attention more widely and more deeply on the inner workings of the contemporary economic and political order, on links between financial criminality and 'normal' financial practices, and on how economic and political power placed bankers above the law. Evidence of wrongdoing is used to cast a longer shadow. The lexicon of crime and criminal censure was widely used by the early populists in the US to describe the powerful corporate interests that victimised small farmers, wage workers, trade unions and political activists (see, for example, Geis 2011: 6). This was mirrored in Australian labour populism's militant criticism of the excesses of 'the money power' (the banks, finance capital and their political allies) dating from the same time. The rhetoric of crime and accusations of moral turpitude pervaded descriptions of the money power in the labour press and in radical analysis. They were regularly depicted as robbers, fraudsters, swindlers, and conspirators whose crimes went unpunished whilst the crimes of their victims - crimes of poverty and desperation - were met with the full force of the law. This was accompanied by demands to prosecute financiers and their political colluders if it was not to be said that there was one law for the rich and another for the poor (Love 1984: 23-26).

As critics of populism correctly point out, this involves gross simplification - reducing a complex social and economic system to a conspiracy on the part of a small clique of capitalists. But this is somewhat beside the point. Criminal labels always abstract and simplify. As populist signifiers, they are effective because of this - because they provide an impressive stock of symbols and meanings that are widely accessible and provide a clear focus for mobilising and channelling 
discontent. Critics of Australian labour populism (like Peter Love) were nevertheless led to acknowledge the kernel of truth in populist depictions of capitalist behaviour.

The law is one of the fundamental mechanisms through which a society seeks to organise its collective life and give expression to its shared norms and values. As Durkheim (1964) (amongst others) stressed, the punitive function and aspect of law (and hence the criminal law) plays a vital role in this because it concerns the most fundamental of these norms and values, tapping most deeply into and energising the psychic, cultural, and social life of society. It should not surprise, then, that discourses around crime and punishment are so often emotive, visceral and polarising. It is one of the principal sites in which the moral politics of society are conducted and in which popular investments are most prolific and passionately felt.

The currency of populist law and order politics is no more than a reflection of these psychosocial and political dynamics. Whilst for some decades it has been attached to a conservative law and order agenda, the times may favour a different sort of populism more in keeping with the focus of earlier progressive populist moments on questions of inequality, power and the transgressions of the wealthy rather than only those of the poor and marginal.

\section{Concluding comments}

The crusade of the new right to overturn the New Deal order in the US rested on a twofold imperative: to free markets in order to reward and encourage enterprise; and to strengthen the law so that individuals were made to bear the responsibility for harming others and given incentives to avoid doing so.

A society in which businesses have become too big to fail and individuals too powerful to gaol regardless of how badly they perform or how much harm they cause is one in which markets and the legal process have been distorted out of shape. This involves a complete breakdown in notions of personal responsibility, reward for enterprise, the rule of law and democracy. It shows that gross inequality, and the 'winner-takes-all' politics it produces, is inconsistent with upholding these notions. The free market ideologues whose policies delivered soaring economic and social inequalities delivered the very opposite of what they promised.

Commentators across a broad political spectrum seem to share these concerns (cf Fukuyama 2012). Even that venerable global beacon of free market thought, The Economist magazine, recently mounted a sustained assault on growing inequalities throughout the world, seeking a new progressive politics centred on attacking monopolies and vested interests, providing social support for the poor and the young and reforming taxes. In the rich world, The Economist concluded, 'Scandinavia is the most inventive region' (2012: 14) and 'the next supermodel' (The Economist 2013: 9).

Such an acknowledgment makes you wonder whether the shibboleths of free market capitalism may be crumbling. The Scandinavian social democracies are high taxing and high spending states. By the lights of free market enthusiasts they are well down 'the road to serfdom'. Almost by any measure, however, they benefit economically (as well as socially) from their rejection of the free market faith in favour of a mixed economy and a strong role for government. They invest generously in the skills, health and social well-being of their citizens. As well as being socially inclusive, they are the most productive and prosperous societies in the world. They happen to be the least punitive societies too (Pratt and Eriksson 2013; Currie 2013). Although not without problems, they show that the degree of inequality a society tolerates and fosters, and how much and who it punishes, are not dictated by the invisible hand of the market but involve political questions and choices. 
Correspondence: Russell Hogg, Associate Professor, School of Justice, Faculty of Law, Queensland University of Technology, Brisbane, Qld 4000, Australia. Email: russell.hogg@qut.edu.au

\section{References}

Alexander M (2012) The New Jim Crow - Mass Incarceration in the Age of Colorblindness. Revised Edition. New York: The New Press.

Anderson M (2013) Clothed in Misery, The New York Times May 1.

Bale T, Van Kessel S and Taggart P (2011) Thrown Around with Abandon? Popular Understandings of Populism as Conveyed by the Print Media: A UK Case Study. Acta Politica April: 111-131.

Bathurst Regional Council v Local Government Financial Services Pty Ltd (No 5) [2012] FCA 1200 (5 November 2012).

Berman W (1994) America's Right Turn - from Nixon to Bush. Baltimore: John Hopkins University Press.

Bertram E, Blachman M, Sharpe K and Andreas P (1996) Drug War Politics - the Price of Denial. Berkeley: University of California Press.

Bottoms A (1995) The Philosophy and Politics of Punishment and Sentencing. In Clarkson C and Morgan R (eds) The Politics of Sentencing Reform. Oxford: Clarendon.

Brown D (2013) Prison Rates, Social Democracy, Neo-liberalism and Justice Reinvestment. In Carrington K, Ball M, O’Brien E and Tauri J (eds) Crime, Justice and Social Democracy International Perspectives. Houndmills: Palgrave Macmillan.

Boyte H and Reissman F (eds) (1986) The New Populism - the Politics of Empowerment. Philadelphia: Temple University Press.

Burchell D and Leigh A (eds) (2002) The Prince's New Clothes: Why Do Australians Dislike Their Politicians? Kensington: UNSW Press.

Duff P (2012), Theories of Criminal Law, Stanford Encyclopedia of Philosophy, accessible online at http://plato.stanford.edu/archives/spr2012/entries/criminal-law/ (accessed 10 May 2013).

Carson W G (1971) White Collar Crime and the Enforcement of Factory Legislation. In WG. Carson and P Wiles (eds) The Sociology of Crime and Delinquency in Britain. London: Martin Robertson.

Carson W G (1979) The Conventionalization of Early Factory Crime. International Journal for the Sociology of Law 7: 37-60.

Chomsky N (2012) Occupy. London: Penguin.

Coffee J (1981) 'No Soul to Damn: No Body to Kick': An Unscandalized Inquiry into the Problem of Corporate Punishment. Michigan Law Review 79: 386-459.

Currie E (2013) The Sustaining Society. In Carrington K, Ball M, O’Brien E and Tauri J (eds) Crime, Justice and Social Democracy - International Perspectives. Houndmills: Palgrave Macmillan.

Denniss R (2013) There is no "opt out" clause, Canberra Times February 2.

Dionne DJ Jr (2012) Our Divided Political Heart - the Battle for the American Idea in an Age of Discontent. New York: Bloomsbury.

Du Bois WEB (1899) The Philadelphia Negro: A Social Study. New York: Kraus-Thompson Organisation Limited.

Durkheim D (1964) The Division of Labor in Society. New York: The Free Press. 
The Economist (2012) True Progressivism: A New Form of Radical Centrist Politics is Needed to Tackle Inequality without Hurting Economic Growth, October 13: 13.

The Economist (2013) The Next Supermodel: Politicians from Both Right and Left Could Learn from the Nordic Countries, February 2: 9.

Ferguson C (2012) Inside Job. Oxford: Oneworld.

Foucault M (1977) Discipline and Punish: The Birth of the Prison. Harmondsworth: Penguin Books.

Freiberg A and Gelb K (eds) (2008) Penal Populism, Sentencing Councils and Sentencing Policy. Annandale: Hawkins Press.

Fukuyama F (2012) The Future of History: Can Liberal Democracy Survive the Decline of the Middle Class. Foreign Affairs 91(1): 53-61.

Garland D (2001) The Culture of Control. Oxford: Oxford University Press.

Geis G (2011) White Collar and Corporate Crime: A Documentary and Reference Guide. Westport, Connecticut: Greenwood.

Goodwyn L (1976) Democratic Promise - The Populist Moment in America. USA: Oxford University Press.

Hall S (1980) Popular-Democratic vs Authoritarian Populism: Two Ways of Taking Democracy Seriously. In Hunt A (ed) Marxism and Democracy. London: Lawrence and Wishart.

Hall S (1983) The Great Moving Right Show. In Hall S and Jacques M (eds) The Politics of Thatcherism. London: Lawrence and Wishart.

Hamilton C (2013) ASIC and the great coal hoax, The Conversation January 18.

Hartcher P (2011) The Sweet Spot - How Australia Made its Own Luck and Could Now Throw it all Away. Collingwood: Black Inc.

Hayek F (1944 (1979)) The Road to Serfdom. London: Routledge and Kegan Paul.

Hogg R (2013) Punishment and "The People": Rescuing Populism from its Critics. In Carrington K, Ball M, O'Brien E and Tauri J (eds) Crime, Justice and Social Democracy - International Perspectives. Houndmills: Palgrave Macmillan.

Katz M (1989) The Undeserving Poor - From the War on Poverty to the War on Welfare. New York: Pantheon Books.

Kazin M (1998) The Populist Persuasion - An American History. Ithaca: Cornell University Press.

Kindleberger C (1996) Manias, Panics, and Crashes - A History of Financial Crises 3rd edn. New York: John Wiley and Sons.

Koller C (2012) White Collar Crime in Housing - Mortgage Fraud in the United States. El Paso: LFB Scholarly Publishing LLC.

Lacey N (2008) The Prisoners' Dilemma - Political Economy and Punishment in Contemporary Democracies. Cambridge: Cambridge University Press (the Hamlyn Lectures 2007).

Laclau E (2007) On Populist Reason. London: Verso.

Leveson, Lord Justice (2012) An Inquiry into the Culture, Practices and Ethics of the Press. London: The Stationery Office.

Lewis M (2011) The Big Short. Camberwell: Penguin.

Lind M (1997) Up from Conservatism - Why the Right is Wrong for America. New York: Free Press.

Love P (1984) Labour and the Money Power - Australian Labour Populism 1890-1950. Melbourne: Melbourne University Press. 
Madrick J and Partnoy F (2011) Should Some Bankers Be Prosecuted? The New York Review of Books November 10.

Mishel L and Bivens J (2011) Occupy Wall Streeters Are Right about Skewed Economic Rewards in the United States. Washington: Economic Policy Institute, Briefing Paper \#331.

Morin R (2012) Rising Share of Americans See Conflict Between Rich and Poor. Pew Research Center January 11.

New York Times (2013) 'Foreclosures (2012 Robosigning and Mortgage Servicing Settlement)', Times Topics February 25.

Nye J, Zelikow P and King D (eds) (1997) Why People Don't Trust Government. Cambridge: Harvard University Press.

O'Malley P (2009) The Currency of Justice - Fines and Damages in Consumer Societies. Oxford: Routledge-Cavendish.

Peacock M (2009) Killer Company - James Hardie Exposed. Sydney: ABC Books.

Pear R (2011) Top Earners Doubled Share of Nation's Income, Study Finds, New York Times October 25.

Potter B (2013) A \$5bn test of credibility. Weekend Australian Financial Review, 9-10 February 9-10: 22.

Pratt J (2006) Penal Populism. London: Routledge.

Pratt J and Eriksson A (2013) Contrasts in Punishment - An Explanation of Anglophone Excess and Nordic Exceptionalism. London: Routledge.

Roberts J, Stalans L, Indermaur D and Hough M (2003) Penal Populism and Public Opinion Lessons from Five Countries. Oxford: Oxford University Press.

Sachs J (2012) The Price of Civilization - Reawakening Virtue and Prosperity after the Economic Fall. London: Vintage.

Shover N and Cullen F (2008) Studying and Teaching White-Collar Crime: Populist and Patrician Perspectives. Journal of Criminal Justice Administration, 19(2): 155-174.

Sinclair U (1906 (1965)) The Jungle. Harmondsworth: Penguin Books.

Stiglitz J (2010) Freefall - Free Markets and the Sinking of the Global Economy. London: Allen Lane.

Stiglitz J (2012) The Price of Inequality. London: Allen Lane.

Stuntz W (2011) The Collapse of American Criminal Justice. Cambridge: Harvard University Press.

Sutherland E (1949) White Collar Crime. New York: Dryden.

Sutherland E (1970) Is 'White Collar Crime' Crime? In Wolfgang M, Savitz L and Johnson N (eds) The Sociology of Crime and Delinquency 2nd edition. New York: John Wiley and Sons.

Taibbi M (2012a) Bank of America: Too Crooked to Fail, Rolling Stone March 29.

Taibbi M (2012b) The Scam Wall Street Learned from the Mafia, Rolling Stone July 5.

Taibbi M (2013) Gangster Bankers: Too Big to Jail, Rolling Stone February 28.

Tappan P (1970) Who is the Criminal? In Wolfgang M, Savitz L and Johnson N (eds) The Sociology of Crime and Delinquency. $2^{\text {nd }}$ edition. New York: John Wiley and Sons.

Tett G (2009) Fool's Gold - How Unrestrained Greed Corrupted a Dream, Shattered Global Markets and Unleashed a Catastrophe. London: Little Brown.

Washington Post (2010) BoA Fined \$137 Million for Fraud, December 8.

Watson T and Hickman M (2012) Dial M for Murdoch. London: Allen Lane. 
Wyatt E (2011a) JPMorgan Settles Case with SEC, New York Times June 21.

Wyatt E (2011b) Promises Made, and Remade, by Firms in S.E.C Fraud Cases, New York Times November 7.

Zeleny J and Thee-Brenan M (2011) New Poll Finds a Deep Distrust of Government, New York Times October 25. 